\title{
PARECER
}

\section{ARGÜIÇĀO DE DESCUMPRIMENTO DE PRECEITO FUNDAMENTAL. INTERPRETAÇÃO CONFORME À CONSTITUIÇÃO DE DISPOSITIVOS DO CÓDIGO PENAL. DECLARAÇĀO DE INCONSTITUCIONALIDADE DA INCIDÊNCIA SOBRE A HIPÓTESE DE ANTECIPAÇÃO DE PARTO DE FETO COMPROVADAMENTE ANENCEFÁLICO.}

EMENTA: Antecipação de parto de feto anencefálico. Comprovação da anomalia mediante laudo médico. Desnecessidade de prévia autorização judicial. Enquadramento no tipo de aborto. Controvérsia jurisprudencial. Ineficácia de ações individuais. Duração do processo não razoável. Ofensa a preceitos fundamentais. Interpretação conforme à Constituição dos dispositivos do Código Penal que disciplinam o tipo penal do aborto. Controle concentrado de constitucionalidade. Meio processual eficaz. Argüição de Descumprimento de Preceito Fundamental. Cabimento. Requisitos satisfeitos. Devido julgamento pelo Supremo Tribunal Federal.

\section{PRÓLOGO}

\section{A CONSULTA}

A Confederação Nacional dos Trabalhadores na Saúde - CNTS, através do ilustre advogado Prof. Dr. Luís Roberto Barroso, honra-nos com a formulação de consulta sobre $o$ cabimento de Argüição de Descumprimento de Preceito Fundamental no caso em que se requer a interpretação conforme à Constituição dos arts. 124, 126 e 128 do Código Penal para o fim de pronunciar a inconstitucionalidade da incidência dos dispositivos na hipótese de antecipação de parto de fetos comprovadamente anencefálicos, declarando-se, para a gestante, o direito subjetivo de submeter-se ao procedimento médico adequado sem necessidade de ordem judicial prévia.
O quesito único apresentado a reclamar a presente manifestação opinativa envolve, portanto, o cabimento da ação constitucional disciplinada pela Lei $n^{\circ} 9.882 / 99$ na hipótese referida.

\section{ESTUDO DO CASO}

\subsection{INTRODUÇÃO}

A Lei $n^{\circ} 9.882$, de 03 de dezembro de 1999 , que regulamentou 0 art. $102, \S 1^{\circ} \mathrm{da}$ Constituição Federal', dispōe sobre a Argüição de Descumprimento de Preceito Fundamental perante o Supremo Tribunal Federal. In verbis:

$1 O \S 1^{\circ}$ do art. 102 da Constituição de 1988 , originalmente parágrafo único, foi renumerado pela Emenda Constitucional $n^{\circ} 3 / 93$.

R. Dir. Adm.,

Rio de Janeiro, 241: 323-365,

Jul./Set. 2005 
Art. $1^{\circ}$. A argüição prevista no $\S 1^{\circ}$ do art. 102 da Constituição Federal será proposta perante o Supremo Tribunal Federal, e terá por objeto evitar ou reparar lesão a preceito fundamental, resultante de ato do Poder Público.

Parágrafo único. Caberá também argüição de descumprimento de preceito fundamental:

I- quando for relevante o fundamento da controvérsia constitucional sobre lei ou ato normativo federal, estadual ou municipal, incluídos os anteriores à Constituição;

$$
\begin{aligned}
& \text { II - (vetado) } \\
& \text { [...] } \\
& \text { Art. } 4^{\circ} \text { Omissis }
\end{aligned}
$$

\section{Art. $4^{\circ}$ Omissis}

$\S 1^{\circ}$ Não será admitida argüição de descumprimento de preceito fundamental quando houver qualquer outro meio eficaz de sanar a lesividade.

Depreende-se do texto legislativo a existência de três requisitos para a argüiçãa de descumprimento de preceito fundamental: (i) ameaça ou violação a preceito fundamental, (ii) causada por ato do Poder Público, (iii) quando não houver outro meio eficaz de tutela. Em que pese a controvérsia em torno da aplicação do inciso I do parágrafo único do art. $1^{\circ}$ da supra mencionada lei, vislumbra-se aí um quarto elemento a demandar manifes- tação: (iv) relevância do fundamento da controvérsia constitucional sobre lei federal, inclusive anterior à Constituição. Embora expressos, tais requisitos não são claros em seu alcance, ensejando certa dose de cautela do intérprete.

Uma vez realizados os pressupostos na ação proposta, torna-se inquestionável o seu cabimento. Analisemos, então, cada um deles em cotejo com a situação aventada.

\subsection{AMEAÇA OU VIOLAÇÃO A PRECEITO FUNDAMENTAL}

A primeira questão que emerge a propósito da configuração da ameaça ou da violação a preceito fundamental envolve o conceito de preceito fundamental. Duvidosos à época da promulgação da Constituição, conceito e alcance da expressão, reafirmados com a edição da Lei ${ }^{\circ} 9.882 / 99$, são hoje passíveis de concordância na doutrina e na jurisprudência.

Uma interpretação sistemática' ${ }^{\prime}$ do Texto Constitucional oferece preciosos elementos para a determinação do que é preceito fundamental. Primeiramente, tem-se que pode ser tanto uma regra quanto um princípio ${ }^{2}$, eis que

1 Para uma leitura atualizada da interpretação sistemática do direito, conferir a obra: FREITAS. Juarez. A interpretação sistemática do direito, 4*. ed., São Paulo: Malheiros. 2004.

2 "Preceito é termo genérico utilizado tanto para designar regra ou dispositivo, como para designar princípio, seja ele expresso ou implícito no texto constitucional." (MANDELLI JR, Roberto Mendes. Argüição de descumprimento de preceito fundamental: instrumento de proteção dos direitos fundamentais e da Constituição. São Paulo: RT, 2003, p. 112) Sobre a distinção entre regras e princípios, vale a pena lembrar as consagradas lições de DWORKIN e ALEXY. Para DWORKIN, "a diferença entre princípios e regras jurídicas é de natureza lógica. Os dois conjuntos de padrões apontam para decisōes particulares acerca da obrigação jurídica em circunstâncias específicas, mas distinguem-se quanto à natureza da orientação que oferecem. As regras são aplicáveis à maneira do tudo-ou-nada. Dados os fatos que uma regra estipula, então ou a regra é válida, e neste caso a resposta que ela fornece deve ser aceita, ou não é válida, e neste caso em, nada contribui para a decisão." (...) "A regra pode ter exceções, mas se tiver. será impreciso e incompleto simplesmente enunciar a regra, sem enumerar as exceções. Pelo menos em teoria, todas as exceções podem ser arroladas e quanto mais o forem, mais completo será o enunciado da regra. Mas não é assim que funcionam os princípios (...). Mesmo aqueles que mais se assemelham a regras não apresentam conseqüências jurídicas que se seguem automaticamente quando as condições são dadas." (...) "Os princípios possuem uma dimensão que as regras não têm - a dimensão do peso ou importância." (DWORKIN, Ronald. Levando os direitos a serio. Tradução de: Nelson Boeira. São Paulo: Martins Fontes. 2002, p. 39-42) Uma releitura das consideraçōes de DWORKIN é oferecida por ALEXY. que acrescenta a caracterização dos princípios como mandados de otimização. Classificando a distinção de qualitativa, ALEXY dá especial relevância para a forma como se soluciona um conflito entre regras 
a Constituição apresenta-se como um sistema aberto composto por ambas as espécies normativas' (3) é um sistema normativo, porque a estruturação das expectativas referentes a valores, programas, funções e pessoas, é feita através de normas; (4) é um sistema de regras $e$ de principios, pois as normas do sistema tanto podem revelar-se sob a forma de princípios como sob a sua forma de regras." (CA. NOTILHO, op. cit., p. 1085). Não é qualquer regra ou princípio, mas tão somente aquele fundamental, ou seja, essencial, basilar ao Estado Democrático de Direito ${ }^{2}$, que aponta para a identidade da Constituição. Encontram-se aí os princípios fundamentais da República (arts. $1^{\circ}$ a $4^{\circ}$, da Constituição), os princípios sensíveis (art. 34, inc. VII, da Constituição), as cláusulas pétreas (art. $60, \S 4^{\circ}$, da Constituição) e os direitos e garantias fundamentais (Título Il da Constituição) ${ }^{3}$, entre outros.

ou entre princípios. Para tanto conceitua as normas, que por sua estrutura, ordenam que algo seja realizado na maior medida possível, dentro das possibilidades jurídicas e reais existentes, como princípios. Portanto, princípios são mandados de otimização que estão caracterizados pelo fato de que podem ser cumpridos em diferentes graus, e que, a medida devida de seu cumprimento não só depende das possibilidades reais, senão também das jurídicas. Desta forma a colisão entre princípios é solucionada com a precedência de um sobre o outro sem declaração de invalidade deste que foi afastado na decisão do caso concreto. (ALEXY, Robert. Teoria de los derechos fundamentales, Tradução de: Ernesto Garzón Valdés. Madrid: Centro de Estudios Constitucionales, 1997.p. 86-89). Sobre a diferença entre regras e princípios, conferir, ainda: BOROWSKI, Martin. La estructura de los derechos fundamentales. Traducción de Carlos Bernal Pulido. Colômbia: Universidad Externado de Colômbia, 2003, p. 47-56; BARROSO, Luís Roberto. Fundamentos teóricos e filosóficos do novo direito constitucional brasileiro: pós-modernidade, teoria crítica e pós-positivismo. Revista da Academia Brasileira de Direito Constitucional, n. 1, 2001, p. 41-54; BARCELLOS, Ana Paula de. A eficácia jurídica dos princípios constitucionais: o princípio da dignidade da pessoa humana. Rio de janeiro: Renovar, 2002, p. 40-57; CANOTILHO, José Joaquim Gomes. Direito Constitucional e teoria da Constituição, 32. ed., Coimbra: Almedina, 1999, p. 1085-1099; ÁVILA, Humberto Bergman. A distinção entre princípios e regras e a redefinição do dever de proporcionalidade. Revista de Direito Administrativo, n. 215,, jan./mar. 1999, p. 151-179; MORO, Sergio Fernando. Jurisdição constitucional como democracia. São Paulo: RT, 2004, p. 184-192; GRAU, Eros Roberto. Ensaio e discurso sobre a interpretação/aplicação do direito. São Paulo: Malheiros, 2002, p. 122-179.

1 Sobre a noção de sistema aberto de regras e princípios, valemo-nos da lição de CANOTILHO: “(1) é um sistema jurídico porque é um sistema dinâmico de normas; (2) é um sistema aberto porque tem uma estrutura dialógica (Caliess), traduzida na disponibilidade e «capacidade de aprendizagem» das normas constitucionais para captarem a mudança da realidade e estarem abertas às concepções cambiantes da «verdade» e da «justiça»;

2 "Entra, aqui, a importância da noção de Estado Democrático de Direito, que, por agregar o conjunto de conquistas da modernidade, nas três dimensões que possuem os direitos fundamentais, constitui, na revolução paradigmática proporcionada pelo novo constitucionalismo do pós-guerra, um verdadeiro plus normativo, no interior do qual o direito é gerido pelo próprio direito, e onde o Estado deve, na sua organização, respeitar a conformação dos direitos sociais e fundamentais. Esse plus normativo, basicamente, ancora-se tanto no conceito 'democrático', como na necessidade do respeito aos direitos fundamentais, donde a realização desses direitos tornam-se [sic] condição de possibilidade para a própria caracterização da democracia. Os mecanismos de realização dos direitos fundamentais assumem lugar cimeiro no contexto do constitucionalismo do Estado Democrático de Direito." (STRECK, Lênio Luiz. Jurisdição constitucional e hermenêutica: uma nova crítica do Direito. Porto Alegre: Livraria do Advogado, 2002, p. 638)

3 "Com a expressão preceitos fundamentais o legislador constitucional pretendeu alcançar todos os direitos e garantias fundamentais. Mas, não somente aqueles que se encontram agasalhados na declaração de direitos; também, na minha avaliação, todos aqueles direitos vinculados ao exercício das liberdades públicas e aos direitos sociais, vinculados à dignidade humana. alcançando, assim, os fundamentos da República, tal e qual definidos no art. $1^{\circ}$ da Constituição Federal, suscetíveis de descumprimento pelo 
Trata-se, então, de um rol exemplificativo e, afirme-se, mínimo, pois se a tais preceitos não pode ser negada a condição de fundamentais, outros, todavia, poderão ser descobertos pela comunidade aberta dos intérpretes da Constituição, para utilizar expressão consagrada de Peter Häberle'.

Ora, limitando-se, o Constituinte de 1988. a enunciar a locução preceito fundamental, acabou, por um lado, dificultando a aplicação da garantia constitucional até sua regulamentação ${ }^{2}$, e por outro, privilegiando a dimensão democrática da Jurisdição Constitucional ${ }^{3}$.
O Supremo Tribunal Federal, enquanto órgão jurisdicional máximo de proteção da Constituição, desenvolve um papel ímpar na construção do conceito de preceito fundamental. Para tanto, deve levar em consideração, no desempenho da tarefa, o escopo democratizador dos direitos fundamentais numa comunidade que é desigual não apenas do ponto de vista material, mas também cultural. ${ }^{4}$

"a função de um Tribunal Constitucional ou de uma Corte Suprema em matéria de constitucionalidade das leis é a de zelar pela garantia dos procedimentos institucionalizados

Poder Público, oriundo o descumprimento de atos abusivos dos Poderes Executivo, Legislativo e Judiciário." (MENEZES DIREITO, Carlos Alberto. Tendências do direito brasileiro: a ampliação da jurisdição constitucional e da proteção dos direitos do homem e do cidadão. A Lei $n^{\circ} 9.882$, de 3 de dezembro de 1999. In MARTINS, Ives Gandra da Silva (coord.). As vertentes do direito constitucional contemporâneo. Rio de Janeiro: América jurídica, 2002, p. 165) A propósito, conferir também MANDELLI JR, op. cit., p. 117-118 e 120; e MENDES. Gilmar Ferreira. Argüição de descumprimento de preceito fundamental: parâmetro de controle e objeto. In TAVARES, André Ramos; ROTHENBURG, Walter Claudius (org.). Argüição de descumprimento de preceito fundamental: análises à luz da Lei $n^{\circ}$ 9.882/99. São Paulo: Atlas, 2001, p. 128-129.

1 HÄBERLE, Peter. Hermenêutica constituciònal: a sociedade aberta dos intérpretes da constituição: contribuição para a interpretação pluralista e "procedimental" da constituição. Tradução por: Gilmar Ferreira Mendes. Rio de Janeiro: Sérgio Fabris Editor, 1997.

2 Para alguns autores, ainda quando inexistente a lei regulamentadora da argüição de descumprimenio de preceito fundamental as violações a preceitos fundamentais deveriam ter sido analisadas nesta via. Não cabe aqui discutir a tese. O que importa lembrar é que tanto antes quanto depois da Lei $n^{\circ} 9.882 / 99$. não é a enumeração de preceitos fundamentais considerada condição de possibilidade de conhecimento e processamento da argüição de descumprimento de preceito fundamental. Neste sentido, conferir STRECK, op. cit., p. 634.

3 "A ausência dessa previsão confere à jurisprudência maior flexibilidade, permitindo alterações quanto à densidade axiológica da norma constitucional, possibilitando acomodar com mais facilidade mudanças na sociedade, aplicando o método da interpretação constitucional evolutiva, deixando espaço tanto para que um preceito constitucional passe a ser tratado como fundamental, bem como para que deixe de sê-lo, pois os preceitos fundamentais decorrem da própria história constitucional do Estado." (MANDELLI JR, op. cit., p. 116) Nesse sentido, CLÈVE, Clèmerson Merlin e DIAS, Cibele Fernandes. Argüição de Descumprimento de Preceito Fundamental. Revista de Direito da Procuradoria Geral do Estado de Goiás, n. 21, jan./dez. de 2001, p. 51; ROTHENBURG, Walter Claudius. Argüição de descumprimento de preceito fundamental. In TAVARES, André Ramos; Argüição de descumprimento de preceito fundamental: análises à luz da lei $n^{\circ}$ 9.882/99. São Paulo: Atlas, p. 212.

4 MENEZES DIREITO nos lembra da lição de Cardoso: "O grande juiz da Suprema Corte dos Estados Unidos da América [Benjamin Nathan Cardoso] ensinou, considerando a 'questão sobre como deveria decidir um juiz diante do conflito entıe suas convicções e as conviç̧ões da comunidade, diante da resposta de um seu colega, que indicavą a predominância das conviç̧ōes pessoais do juiz', que: 'Não se verificará, provavelmente na prática. Raro, na verdade, será o caso em que nada exista para inclinar a balança, além das noções contraditórias sobre o procedimento correto. Se, entretanto, o caso suposto aqui estivesse, creio que erraria o juiz qu'e quisesse impor à comunidade, como norma de vida, suas próprias idiossincrasias de procedimento ou de crença." (Op. cit., p. 164) 
aptos à geração de provimentos estatais como mecanismo de tutela da democracia." 1

É claro que o debate em si comporta a defesa de todos os pontos de vista; porém, ao Supremo Tribunal Federal, àquele que vai dar a última palavra no contencioso judicial, cumpre referendar o pluralismo inerente ao Estado Democrático de Direito ${ }^{2}$. Por mais difícil que a tarefa possa se apresentar, é preciso considerar que a eficácia dos direitos fundamentais não pode ficar restringida aos núcleos de interesses da maioria ${ }^{3}$.

Um espaço que se pretenda democrático, não obstante, a legitimidade dos atos públicos, incluídos aí os normativos, administrativos e jurisdicionais, haverá de guardar consonância com o debate público, responsável pela atualização de significado dos comandos estatais $^{4}$. 5. $\mathrm{Na}$ era tecnológica ${ }^{6}$, em razão da velocidade com que as relações sociais se

1 CRUZ, Álvaro Ricardo de Souza. Jurisdiçāo Constitucional Democrática. Belo Horizonte: Del Rey. 2004, p. 439.

2 "O Estado Democrático de Direito, em que se constitui a República Federativa do Brasil, assegura os valores de uma sociedade pluralista (Preâmbulo) e fundamenta-se no pluralismo político (art. $1^{\circ}, \mathrm{V}$ ). A Constituição opta, pois, pela sociedade pluralista que respeita a pessoa humana e sua liberdade. em lugar de uma sociedade monista que mutila os seres e engendra as ortodoxias opressivas. O pluralismo é uma realidade, pois a sociedade se compõe de uma pluralidade de categorias sociais, de classes, grupos sociais, econômicos, culturais e ideológicos. Optar por uma sociedade pluralista significa acolher uma sociedade conflitiva, de interesses contraditórios e antinômicos. O problema do pluralismo está precisamente em construir o equilíbrio entre as tensões múltiplas e por vezes contraditórias, em conciliar a sociabilidade e o particularismo, em administrar os antagonismos e evitar divisões irredutíveis." (SILVA, José Afonso. Curso de Direito Constitucional Positivo, $21^{*}$ ed., São Paulo: Malheiros, 2002, p. 143) Conferir, ainda, BURDEAU, Georges. Traité de science politique. $2^{\star 2}$ ed., T. I p. 185, T. III p. 169 e T. VII, Paris: LGDJ, 1966 a 1977, p. 559-56; HAURIOU, André. Droit constitutionnel et institutions politiques, 5' ed., Paris: ed. Montchrestien, 1972, p. 226.

3 "A maioria não pode dispor de toda a «legalidade», ou seja, não Ihe está facultado, pelo simples facto de ser maioria, tornar disponível o que é indisponível, como acontece, por ex., com os direitos, liberdades e garantias e, em geral, com toda a disciplina constitucionalmente fixada (o princípio da constitucionalidade sobrepõe-se ao princípio maioritário). (...) O princípio maioritário não exclui, antes respeita, o «pensar de outra maneira», o «pensamento alternativo». Noutros termos: o princípio maioritário assenta politicamente num «relativismo pragmático» e não num «fundamentalismo de maiorias». Para utilizarmos as palavras de um ex-presidente do Tribunal Constitucional Alemão: o pressuposto básico da praticabilidade do princípio maioritário é a ausência de pretensões absolutas de verdade." (CANOTILHO, op. cit., p. 316-317)

4 "Não é demais lembrar que a vida é muito mais rica e complexa que a melhor das teorias. Portanto, cumpre, sim, manter a coerência dos postulados teóricos e doutrinários, mas nem por isso está-se autorizado a desprezar as exigências e desafios que a experiência vai impondo às condutas humanas e às categorias jurídicas. Cabe à jurisprudência a e ao Judiciário, a insubstituível tarefa de, observados os valores que o direito não pode descurar, atualizar o sentido dos preceitos legais e a utilidade das formulações teóricas, adaptando uns e outras aos renovades fatos que a vida oferece todos os dias." CLÈVE, Clèmerson Merlin. A fiscalização abstrata da constitucionalidade no direito brasileiro, 2 ed., São Paulo: RT, 2000, p. 255.

5 “cidadãos e grupos, órgãos estatais, o sistema público e a opinião pública (...) representam forças produtivas de interpretação (Interpretatorische Produktivkräfte): eles são intérpretes constitucionais em sentido lato, atuando nitidamente, pelo menos, como pré-intérpretes (Vorinterpreten). Subsiste sempre a responsabilidade da jurisdição constitucional, que fornece, em geral, a última palavra sobre a interpretação (com a ressalva da força normatizadora do voto minoritário). Se se quiser, tem-se aqui uma democratização da interpretação constitucional. Isso significa que a teoria da interpretação deve ser garantida sob a influência da teoria democrática. Portanto, é impensável uma interpretação da constituição sem o cidadão ativo e sem as potências públicas mencionadas." (HABËRLE, op. cit.. p. 14) 
transformam, nem é preciso que a época da edição da lei seja tão distante para que o intento original que a moveu, acaso aferível, possa se apresentar, eventualmente, como exigente de compreensão atualizadora.

"Em verdade, após a edição da lei, esta assume tal autonomia que o seu alcance e sentido serão, efetivamente, definidos pela comunidade jurídica, incluindo as pessoas leigas de uma determinada sociedade. Um mesmo texto de lei, após reiterada interpretação, vai 'amadurecendo' seu sentido e alcance, seja no debate que se estabelece nos meios de comunicação, seja na leitura que se faz nos Tribunais."'

Não se olvida que, com a complexização das relações sociais, a tutela dos direitos fundamentais tem apresentado crescentes dificuldades hermenêuticas em razão das questões delicadas que chegam ao Judiciário. A utilização do princípio da proporcionalidade evidencia isso ${ }^{2}$. Mesmo nestes casos difíceis é imperativo harmonizar os preceitos, senão, restringi-los o mínimo possível. Seja qual for

6 "Em grande parte, a tecnologia expressa a habilidade de uma sociedade para impulsionar seu domínio tecnológico por intermédio das instituições sociais, inclusive o Estado. O processo histórico em que esse desenvolvimento de forças produtivas ocorre assinala as características da tecnologia e seus entrelaçamentos com as relações sociais. Não é diferente no caso da revolução tecnológica atual. Ela originou-se e difundiu-se, não por acaso, em um período histórico da reestruturação global do capitalismo, para o qual foi uma ferramenta básica. Portanto, a nova sociedade emergente desse processo de transformações é capitalista e também informacional." CASTELLS, Manuel. A sociedade em rede, vol. I, $7^{\star 2}$. ed. Tradução de: Roneide Venâncio Majer. São Paulo: Paz e Terra. 2003, p. 49-50.

1 APPIO, Eduardo. Interpretação conforme à Constituição: instrumento de tutela jurisdicional dos direitos fundamentais. Curitiba: Juruá, 2002, p. 30.

2 O Supremo Tribunal Federal tem reiterado a aplicação do princípio da proporcionalidade como meio de testar a racionalidade das restrições aos direitos fundamentais. Cita-se como precedentes anteriores à promulgação da atual Constituição as decisões proferidas no RE $n^{\circ} 18.331$, Rel. Min. Orozimbo Nonato. em que ficou assentado que "o poder de taxar não pode chegar à desmedida do poder de destruir"; na Representação $n^{\circ}$ 930, Rel. Min. Rodrigues Alckmin, tratando das condiçôes de capacidade para o exercício das profissões; na Representação no 1.077 (RTJ 112:34) e na Representação $n^{\circ} 1054$ (RTJ 110:937 e ss.). A referência expressa à aplicação do princípio veio a acontecer já sob a égide da nova ordem constitucional, na ADIn $n^{\circ} 855-2$, onde se discutia a obrigação determinada em lei paranaense de pesagem de botijōes de gás à vista do consumidor no momento da venda, com pagamento imediato da eventual diferença a menor. Ainda em sede cautelar, reconheceu o Supremo Tribunal Federal manifestar-se hipótese de violação ao princípio da proporcionalidade e razoabilidade das leis restritivas de direitos. Decisões dotadas de sentido semelhante são encontradas nas ADIn $n^{\circ} 1.158, n^{\circ} 966-4, n^{\circ} 958-3$ e $n^{\circ}$ 2.019-MC. O manejo da técnica na jurisprudência do Supremo Tribunal Federal pode ser encontrado. ainda, no $\mathrm{HC} \mathrm{n}^{\circ} 71.374-4$, sobre a possibilidade da condução coercitiva do paciente para colheita de material indispensável ao exame de DNA em ação de investigação de paternidade e no MS 23.466, sobre quebra de sigilo bancário. Há ainda vários casos atuais em que transparece o manejo do princípio da proporcionalidade. Não cabe aqui trazer a lista exaustiva dos julgados da Suprema Corte brasileira para demonstrar que aquele se apresenta já como solução metódica incorporada ao cotidiano de sua atividade jurisdicional. Sobre o tema, conferir: MENDES, Gilmar Ferreira. Direitos Fundamentais e controle da constitucionalidade: estudos de direito constitucional. São Paulo: Celso Bastos editor, 1998. p. 67-83; STUMM, Raquel Denise. Princípio da proporcionalidade no direito constitucional brasileiro. Porto Alegre: Livraria do Advogado, 1995: p. 89-93; SANTOS, Gustavo Ferreira. O princípio da proporcionalidade na jurisprudência do Supremo Tribunal Federal: limites e possibilidade. Rio de Janeiro: Lumen Juris, 2004, p. 157-200; SARMENTO. Daniel. A ponderação de interesses na constituição Federal. Rio de Janeiro: Lúmen Júris, 2003, p. 171-193; CLÉVE, Clèmerson Merlin. Contribuiçōes Previdenciárias. Não-recolhimento. Art. 95, d, da Lei 8.212/91. Inconstitucionalidade. RT, v. 736, 1997, p. 521-526; BARROS, Suzana de Toledo. $O$ princípio da proporcionalidade e o controle de constitucionalidade das leis restritivas de direitos fundamentais, $3^{*}$ ed.. Brasília: Brasília Jurídica, 2003, p. 104-130. 
a circunstância, as vedações constitucionais expressas são barreiras intransponíveis, e dentre elas pode-se citar a proibição de o Poder Público, em qualquer âmbito, estabelecer vínculos religiosos (art. 19, inc. I, da Constituição), de criar diferenciações entre brasileiros (art. 19, inc. III; art. $5^{\circ}$, caput e art. $3^{\circ}$, inc. IV, da Constituição) e de discrirninar direitos e liberdades (art. $5^{\circ}$, inc. XLI da Constituição). A suspeita de contrariedade a qualquer destas situações dá ensejo ao mecanismo devido de tutela.

A ameaça ou violação de preceito fundamental nem sempre será patente, haja vista o intercâmbio valorativo que permeia as normas protetoras de tais direitos. Ora, sendo certo que os direitos fundamentais não são absolutos e que seus contornos dificilmente são aferíveis em abstrato, é preciso fazer uso de métodos hermenêuticos arrojados para se identificar tanto o preceito quanto o ato ofensivo. Nesse intuito cunharam-se os princípios da interpretação constitucional, dentre os quais se ressalta o princípio da unidade da Constituição', o princípio da força normativa da Constituição ${ }^{2}$ e o princípio da concordância prática ${ }^{3}$.

1 Tido como mais importante, o princípio da unidade da Constituição significa que "a conexão e a interdependência dos elementos individuais da Constituição fundamentam a necessidade de olhar nunca somente a norma individual, senão sempre também a conexão total na qual ela deve ser colocada, todas as normas constitucionais devem ser interpretadas de tal modo que contradições com outras normas sejam evitadas." (HESSE, op. cit., p. 65) Disto pode-se retirar fundamento tanto para inexistência de hierarquia normativa entre normas constitucionais, quanto para limitação ou restrição a direitos fundamentais e para a necessidade de harmonização de divergências entre disposições de direitos fundamentais. Cf. STEIN. METZ, Wilson Antonio. Colisão de direitos fundamentais e princípio da proporcionalidade. Porto Alegre: Livraria do Advogado, 2001, p. 94-95; STUMM, op. cit., p. 56-58.

2 O princípio da força normativa da Constituição, segundo HESSE, indica que se deve dar preferência aos pontos de vista que proporcionam força de efeito ótimo às normas da Constituição. (HESSE. op. cit., p. 68) Sua inobservância no âmbito dos direitos fundamentais gera consequiências graves, como afirma STEINMETZ: “A perda da força normativa significaria fazer dos direitos fundamentais. como no passado, meras declarações políticas, sem força vinculante. Seria voltar ao tempo em que esses direitos estavam à livre disposição do legislador, apenas ganhando força jurídica quando objeto de lei." (STEINMETZ, op. cit., p. 96)

3 O princípio da concordância prática é a harmonização, otimização dos bens jurídicos protegidos constitucionalmente. Ensina HESSE: "O desenvolvimento da atualidade na resolução de problemas jurídico-constitucionais torna necessária geralmente e em medida crescente comparação de direito que, com razão, foi qualificada de parte integrante indispensável da interpretação constitucional moderna. Em conexão estreita com isso está o princípio da concordância prática: bens jurídicos protegidos jurídicoconstitucionalmente devem, na resolução do problema, ser coordenados um ao outro de tal modo que cada um deles ganhe realidade. Onde nascem colisões não deve, em 'ponderação de bens' precipitada ou até 'ponderação de valor' abstrata, um ser realizado à custa do outro. Antes, o princípio da unidade da Constituição põe a tarefa de uma otimização: a ambos os bens devem ser traçados limites, para que ambos possam chegar à eficácia ótima. Os traçamentos dos limites devem, por conseguinte, no respectivo caso concreto ser proporcionais; eles não devem ir mais além do que é necessário para produzir a concordância de ambos os bens jurídicos. 'Proporcionalidade' expressa, nessa conexão, uma relação de duas grandezas variáveis e precisamente esta que satisfaz melhor aquela tarefa de otimização, não uma relação entre uma 'finalidade' constante e um 'meio' variável ou vários." (HESSE, op. cit., p. 66-67) BORNHOLDT atribui um conteúdo formal ao princípio da concordância prática, ao afirmar que "não possui ele um conteúdo próprio, dependendo, ademais, da dogmática particular de cada direito fundamental colidente. Simplesmente, imporá ele que nenhum direito seja sacrificado, devendo ser ao máximo otimizado." (BORNHOLDT, Rodrigo Meyer. Colisão entre direitos fundamentais: metódica estruturante e ponderação. Curitiba, 2001. 166 f. Dissertação (Mestrado em Direito) - Setor de Ciências Jurídicas, Universidade Federal do Paraná, p. 146) 
Importa ao intérprete resguardar a unidade da Constituição e proteger sua supremacia no ordenamento jurídico. À jurisdição constitucional cabe inegavelmente o papel de instância adequada para a garantia da coerência que as normas infraconstitucionais devem guardar com o corpo da Constituição, no qual se encontram os preceitos fundamentais.

No caso em apreço, em sede de argüição de descumprimento de preceito fundamental, alegou-se a violação aos seguintes preceitos fundamentais: (i) dignidade da pessoa humana (art. $1^{\circ}$, inc. IV, da Constituição); (ii) princípio da legalidade, liberdade e autonomia privada (art. $5^{\circ}$, inc. II, da Constituição); e (iii) direito à saúde (arts. $6^{\circ}$, caput e 196, da Constituição). Sem pretender entrar no mérito da demanda, cumpre avaliar (i) se tais elementos configuram preceitos fundamentais e (ii) se é plausível sua violação ou ameaça por ato do Poder Público consubstanciada inclusive em decisões judiciais fundadas em interpretação inconstitucional de dispositivos do Código Penal.

A partir dos dados teóricos explicitados, a constatação patente é de que todos os preceitos invocados encontram-se na base da identidade política, social e cultural da comunidade, residindo, portanto, no círculo óbvio dos preceitos fundamentais. De fato, ninguém alegaria o contrário sem incorrer em grave risco de esvaziar o conteúdo material da Constituição. Calha aqui o alerta de Cláudio Pereira de Souza Neto:

"Deve o método de interpretação buscar realizar o interesse público e o bem-estar ge- ral, inevitavelmente afetados pela concretização das normas constitucionais, e não só se ater a preocupações com a correção formal da operação silogística. Para isso, torna-se inevitável a utilização de teorias capazes de refletir sobre a constituição não só do ponto de vista lógico-formal, mas também sobre o prisma dos reflexos concretos da norma constitucional interpretada na realidade social."

Identificados os preceitos fundamentais, cumpre analisar a lesividade e sua decorrência de ato do Poder Público.

\subsection{DECORRÊNCIA DE ATO DO PODER PÜBLICO}

Não é o caso aqui de discorrer sobre os atos do Poder Público, seu conceito ou natureza. Importa avançar.

Não tendo a Constituição nem a Lei regulamentadora da argüição de descumprimento de preceito fundamental especificado quais atos do Poder Público são sujeitos ao controle por meio de argüição de descumprimento de preceito fundamental, resta claro que toda a gama deles é abrangida, desde que estejam configurados os demais pressupostos de cabimento ${ }^{2}$. Disto decorre uma conclusão importante: nenhum ato emanado do Poder Público. seja legislativo, administrativo ou jurisdicional, pode ser a priori excluído do controle via argüição de descumprimento de preceito fundamental em razão de sua natureza ${ }^{3}$.

1 SOUZA NETO. Cláudio Pereira. Jurisdiçāo constitucional, democracia e racionalidade prática. Rio de Janeiro: Renovar, 2002, p. 166.

2 "Nota-se que o dispositivo não disse, nem especificou qual dos Poderes Públicos e nem tampouco falou e/o [sic] quais espécies de atos oriundos destes Poderes serão (seriam) objeto da ADPF. Em face deste 'silêncio eloquiente' quanto aos Poderes Públicos subentende-se que esta prescrição abrange tanto o próprio Judiciário. como o Executivo e o Legislativo, não obstante a reticência do STF em entrar/invadir a esfera/competência dos outros em determinados aspectos 'políticos' que envolvam preceitos fundamentais." PAGANELA, Marco Aurélio. A argüição de descumprimento de preceito fundamental no contexto do controle da constitucionalidade. São Paulo: LTr, 2004, p. 80.

3 "A expressão ato do Poder Público, empregada pelo legislador, deve ser compreendida em seu sentido mais lato." SARMENTO, Daniel. Apontamentos sobre a arguiição de descumprimento de preceito fundamental. In TAVARES, André Ramos: ROTHENBURG, Walter Claudius (org.). Argüição de descumprimento de preceito fundamental: análises à luz da Lei n 9.882/99. São Faulo: Atlas, 2001, p. 91. 
É bem verdade que o Supremo Tribunal Federal criou exceções, tais como os atos políticos, que, ainda que provindos de autoridade pública, foram excluídos do âmbito de aplicação da arguiição de descumprimento de preceito fundamental'. O mesmo ocorreu em relação ao cabimento de ação direta de inconstitucionalidade contra atos normativos anteriores à Constituição ${ }^{2} \mathrm{e}$ atos normativos secundários ${ }^{3}$.

Bem se vê que a criação e a regulamentação da argüição de descumprimento de preceito fundamental no sistema de controle de constitucionalidade pátrio trouxeram novos horizontes nesta seara ${ }^{4}$. Enquanto mecanismo inovador, a argüição de descumprimento de preceito fundamental tem um campo próprio de atuação, não coincidente com o que até então era objeto das ações diretass.

"não há equivalência ou simetria entre o antigo objeto das ações diretas (relativamente aos preceitos fundamentais) e a atual argüição, já que a esfera de incidência desta engloba também a impugnação de atos concretos e até de atos não estatais, o que nunca esteve inserido nas ações genéricas de controle de constitucionalidade, assim como omissões, que tradicionalmente também não contavam com remédio adequado, senão a partir da própria Carta de 1988." 6

O caso em apreço não tem por objeto ato político ou ato normativo secundário, mas, sim, ato legislativo cuja interpretação e aplicação em tempos modernos não lograram consenso acerca dos procedimentos médicos permitidos.

Os enunciados normativos elaborados antes da vigente Constituição para compor o tipo penal do aborto encaixam-se perfeitamente na hipótese de ato do Poder Público impugnável via argüição de descumprimento de preceito fundamental, eis que, quando aplicados aos casos de gestação de feto anencefálico, dão margem à construção de normas de decisão potencialmente ofensivas aos hodiernos contornos de certos direitos fundamentais.

Nesta linha, quando observados atos legislativos e/ou jurisdicionais fundados em interpretação desconforme à Constituição, dúvida não haverá sobre a possibilidade de ser objeto

1 ADPF (QO) 1-RJ, Rel. Min. Néri da Silveira, julg. em 03/02/2000. Informativo STF 176.

2 ADIn 02, Rel. Min. Paulo Brossard, j. em 06/02/1992; ADIn 129. Rel. Min. Francisco Rezek, j. em 07/02i1992, DJU 28/08/1992; ADIn 454, Rel. Min. Marco Aurélio: ADIn 30, Rel. Min. Marco Aurélio. julg. em 11/06/1997. DJU 15/08/1997.

3 ADInMC 360-DF, Rel. Min. Moreira Alves, julg. em 21/09/1990, DJU 26/02/1993; ADInMC 1253-DF, Rel. Min. Carlos Velloso, julg. em 30/06/1994, DJU 25/08/1995; ADInMC 1590-SP, Rel. (para o acórdão) Min. Sepúlveda pertence, j. em 19/06/1997, DJU 15/08/1997.

4 "De certa forma, a argüição de descumprimento vem completar o sistema de controle de constitu. cionalidade de perfil relativamente concentrado no Supremo Tribunal Federal, uma vez que as questões que até então não podiam ser apreciadas no âmbito do controle abstrato de constitucionalidade (ação direta de inconstitucionalidade e ação declaratória de constitucionalidade) serão objeto de exame no âmbito do novo procedimento." (MENDES. Argüição de descumprimento ... p. 135)

$5 \quad$ "... a nova lei [Lei $n^{\circ}$ 9.882/99] traz uma novidade em controle concentrado de constitucionalidade. fazendo o país se lançar à frente mais uma vez neste campo. dando mais um passo em direção ao respeito à cidadania e ao Estado de Direito. Cria, a lei, um contiole de ampla eficácia (erga omnes), sobre atos não legislativos e, também, atos municipais. Isto fica claro quando, da leitura dos arts. $1^{\circ}$ e $2^{\circ}$, percebe-se que a lei se refere a "ato do poder público", sem restrições categóricas." BASTOS, Celso Ribeiro e VARGAS, Aléxis Galiás de Souza. Argüição de descumprimento de preceito fundamental. Revista de Direito Constitucional e Internacional, n. 30, jan./mar de 2000, p. 70.

6 TAVARES, André Ramos. Argüição de descumprimento de preceito fundamental: aspectos essenciais do instituto na Constituição e na Lei. In ; ROTHENBURG, Walter Claudius (org.). Argüiçāo de descumprimento de preceito fundamental: análises à luz da Lei n 9.882/99. São Paulo: Atlas, 2001, p. 46. 
de controle concentrado de constitucionalida$\mathrm{de}^{\prime}$. Com isso protege-se o preceito fundamental violado e a segurança jurídica de uma só vez.

Na ação proposta perante o Supremo Tribunal Federal não se observa a discussão, certamente mais polêmica, sobre a legalização do aborto $^{2}$, ou seja, sobre se a interrupção da gravidez em todo e qualquer caso, independentemente do motivo, deve ser descriminalizada. Da mesma forma, não se está questionando a constitucionalidade do aborto quando indispensável para salvar a vida da mãe ou de interrupção de gravidez resultante de estupro.

Ninguém desconhece que a Constituição tutela o direito à vida, inclusive do nascituro. Nessa linha, vários direitos fundamentais foram consagrados, como a proibição da tortu$\mathrm{ra}^{3}$ ou da pena de morte ${ }^{4}$, e como o direito de tutela da família e da sociedade e a proibição de violência e abuso de crianças e adolescentes $^{5}$. Qualquer ato que encerre prematuramente o desenvolvimento potencial de uma pessoa pode ser punido. Não é preciso tomar partido na discussão para se perceber que a anencefalia não se apresenta como um ato, mas sim como um fato alheio a qualquer vontade $\mathrm{e}$ independente de qualquer causa intencional. Este fato impossibilita o desenvolvimento do feto com vida, ainda que as técnicas mais modernas da medicina estejam à disposição.

A situação descrita, sempre delicada, diante das distintas óticas dos distintos órgãos jurisdicionais, vem gerando insegurança.

"Em um sistema dotado de órgão de cúpula que tem missão de guarda da Constituição a multiplicidade ou a diversidade de soluções pode constituir-se, por si só, em uma ameaça ao princípio constitucional da segurança jurídica e, por conseguinte, em uma autêntica lesão a preceito fundamental." 6

Não se pretende discutir aqui o acerto ou não do entendimento segundo o qual a interrupção da gestação de feto anencefálico é aborto: entretanto, não é dado ignorar que inexiste regra específica tratando do assunto - para permitir ou proibir - em nosso ordenamento.

1 Ademais, a Lei $\mathrm{n}^{\circ}$ 9.882/99 deixa explícita a possibilidade de controle de constitucionalidade de interpretação judicial de preceitos fundamentais ao dispor em seu art. 10. caput, que entre os efeitos possíveis da decisão de argüição de descumprimento de preceito fundamental está a fixação das condições e modo de interpretação de preceitos fundamentais, para o que certamente poderá se valer o Supremo Tribunal Federal da interpretação conforme à Constituição ou da declaração parcial de inconstitucionalidade sem redução de texto. Neste sentido, conferir ROTHENBURG, op. cit., p. 227.

2 DWORKIN conceitua aborto como sendo a prática de " matar deliberadamente um embriāo humano em formação"; uma opção pela "morte antes que a vida tenha realmente começado." In Dominio da vida: aborto, eutanásia e liberdades individuais. Tradução de: Jefferson Luiz Camargo. São Paulo: Martins Fontes, 2003, p. 01.

3 Art. $5^{\circ}$. III - ninguém será submetido a tortura nem a tratamento desumano ou degradante;

4 Art. $5^{\circ}$, XLVII - não haverá penas: a) de morte, salvo em caso de guerra declarada, nos termos do art. 84, XIX;

5 Art. 227 - É dever da família, da sociedade e do estado assegurar à criança e ao adolescente, com absoluta prioridade, o direito à vida, à saúde, à alimentação, à educação, ao lazer, à profissionalização, à cultura. à dignidade, ao respeito, à liberdade e à convivência familiar e comunitária, além de colocá-la a salvo de toda forma de negligência, discriminação, exploração, violência, crueldade e opressão.

6 MEIRELLES, Hely Lopes. Mandado de Segurança, ação popular, ação civil pública, mandado de injunção, hábeas data, ação direta de inconstitucionalidade, ação declaratória de constitucionalidade. argüição de descumprimento de preceito fundamental, controle incidental de normas no Direito Brasileiro. 27'. ed., atual. e compl. por Arnold Wald e Gilmar Ferreira Mendes. São Paulo: Malheiros. 2004, p. 444. 
No mundo contemporâneo, os princípios constitucionais assumem uma importância ímpar, irradiando' seus efeitos por todo o ordenamento jurídico para conformar, desta feita, a interpretação de outras normas. Da mesma forma que as lacunas do direito, que um dia autorizaram a discricionariedade do julgador, foram gradativamente sendo combatidas e repelidas, a adstrição do intérprete aos princípios constitucionais foi se firmando como standard jurídico vinculante para a fiscalização de normas e atos infraconstitucionais ${ }^{2}$.

Se a leitura das condutas tipificadas nos arts. 124, 126 e 128 do Código Penal em face dos preceitos fundamentais consagrados na Constituição atual não comporta a inclusão nas hipóteses ali descritas da antecipação do parto de feto anencefálico, as decisões em sentido contrário, seja por este ou por outro fundamento, desafiam a manifestação da Corte Constitucional. Temos aí um caso constitucional, possivelmente difícil, exigente de solução jurisdicional.

"Pode ocorrer uma lesão a preceito fundada em simples interpretação judicial do texto constitucional. Nesses casos, a controvérsia não tem por base a legitimidade ou não de uma lei ou de um ato normativo, mas se assenta simplesmente na legitimidade ou não de uma dada interpretação constitucional. No âmbito do recurso extraordinário, essa situação apresenta-se como um caso de decisão judicial que contraria diretamente a Constituição (art. 102, III, a).

Não parece haver dúvida de que, diante dos termos amplos do art. $1^{\circ}$, da Lei $n^{\circ} 9.882 / 99$, essa hipótese poderá ser objeto de argüição de descumprimento - lesão a preceito fundamental resultante de ato do Poder Público -. até porque se cuida de uma situação trivial no âmbito de controle de constitucionalidade difuso.

Assim, $o$ ato judicial de interpretação direta de um preceito fundamental poderá conter uma violação da norma constitucional. Nessa hipótese, caberá a propositura da argüição de descumprimento para se evitar a lesão a preceito fundamental resultante desse ato judicial do Poder Público, nos termos do art. $1^{\circ}$ da Lei $\mathrm{n}^{\circ}$ 9.882/99." 3

Tendo em conta que o caso envolve preceitos fundamentais e que a aplicação dos atos legislativos referidos tem revelado dúvida plausível sobre o tratamento jurídico dado à antecipação de parto de feto anencefálico, conclui-se, neste ponto, estarem presentes os dois primeiros requisitos apontados para o cabimento da argüição de descumprimento de preceito fundamental.

1 Sobre o efeito de irradiação dos direitos fundamentais, conferir ALEXY, op. cit., p. 507-510; STEINMETZ, Wilson Antônio. A vinculação dos particulares a direitos fundamentais. São Paulo: Malheiros: 2004, p. 123-128.

2 As críticas de DWORKIN à teoria positivista de HART desempenharam um papel importante para a teoria dos princípios. Em breve síntese, as principais características da teoria positivista (defendida por HART) refutadas por DWORKIN foram: (i) regras de direito são assim consideradas pelo modo como foram criadas ou desenvolvidas, com o propósito de o poder público punir certos comportamentos; (ii) só há obrigação legal se fundada em regra jurídica válida; (iii) se um caso não pode ser decidido pelas regras jurídicas que existem, a ele não se aplicará o direito. O maior argumento de DWORKIN contra o império de regras do positivismo jurídico é a existência de outros standarts, como os princípios e as políticas públicas. Os princípios são os requisitos de justiça, cujo conteúdo admite com exclusividade uma dimensão de peso ou importância. Para o autor, não há como se falar em discricionariedade do juiz para resolver um caso difícil (ao menos não no sentido que os positivistas dão à discricionariedade), pois as argumentações e decisões aí apelam para princípios jurídicos. Assim, indigna-se com teorias da decisão judicial que afirmam que em hipótese alguma juízes devem "criar direito". Isso não teria cabimento principalmente pela atividade de interpretação e pela necessidade de decidir os casos difíceis. Afirma que não há tensão entre originalidade judicial e história institucional. Cf. DWORKIN, op. cit., p. 23-203.

3 MENDES, Argüição de descumpriments..., p. 143. 


\subsection{SUBSIDIARIEDADE}

Antes de mais, é preciso dizer que a configuração do pressuposto da subsidiariedade somente comporta, no presente caso, uma exceção condicional, qual seja, a compreensão de que a técnica da interpretação conforme à Constituição, quando aplicada a dispositivos pré-constitucionais desqualifica a hipótese de revogação ou não recepção que autoriza a restrição do acesso à jurisdição constitucional nos termos da jurisprudência do Supremo Tribunal Federal.

Feita a ressalva, cumpre enfrentar o tema.

Embora não contemplada no texto da Carta Magna, a subsidiariedade foi inserida pelo legislador entre os pressupostos de cabimento da argüição de descumprimento de preceito fundamental. Ainda que sua constitucionalidade seja questionável, não é necessário aprofundar essa investigação para a conclusão do presente estudo. Basta lembrar que, uma vez admitida, a subsidiariedade deve ser compreendida de acordo com o escopo da medida. Assim, tendo em vista a criação desta ação constitucional para tutelar preceitos fundamentais, seria inconstitucional transformá-la em instituto decorativo.

Neste sentido ensina MENEZES DIREITO:
"Não creio que se deva minimizar a argüição pelo fato de existirem tantos outros meios disponíveis. Deve ser considerada a natureza da argüição no sentido de que busca o cumprimento de determinado preceito fundamental. O objetivo é permitir a cessação da lesão, devendo prevalecer o temperamento necessário para admitir a argüição diante de um interesse relevante capaz de autorizar uma intervenção imediata e antecipada do Supremo Tribunal Federal, se, por exemplo, mesmo disponível e utilizado, o outro meio não se mostrar eficaz para cessar ou reparar o descumprimento." 1

Não há prejuízo deste entendimento se uma argüição de descumprimento de preceito fundamental proposta deixar de ser conhecida em virtude da existência de outro meio de tutela do preceito fundamental quando ofereça resultado processualmente mais satisfatório ${ }^{2}$. Uma exigência quase irracional no sentido de que a subsidiariedade da argüição de descumprimento de preceito fundamental tome como referência toda e qualquer medida judicial, inclusive o recurso extraordinário, fatalmente tornaria inócua essa ação constitucional ${ }^{3}$, ferindo frontalmente a Constituição. ${ }^{4}$

Não se busca delinear exceções à aplicação do princípio da subsidiariedades ${ }^{5}$ mas tão-so-

\section{MENEZES DIREITO, op. cit., p. 167.}

2 O STF já teve oportunidade de se manifestar sobre o alcance da subsidiariedade da argüição de descumprimento de preceito fundamental no julgamento da $\mathrm{ADPF} \mathrm{n}^{\circ} 04$, em que se decidiu que o outro meio há de ser eficaz. Esse entendimento deve ser conjugado, ainda, com o caráter principiológico das normas constitucionais que lhes caracteriza como mandados de otimização. Assim, o outro meio somente terá o condão de afastar o cabimento da ADPF se oferecer uma solução mais eficaz para o caso. A expressão destacada é utilizada por ALEXY para identificar nos princípios a qualidade de ordenar que algo seja realizado na maior medida possível dentro das possibilidades jurídicas e reais existentes. Cf. ALEXY, op. cit., p. 86.

3 “... não se torna desarrazoado afirmar que a exigência que a lei regulamentadora faz do esgotamento das vias judiciárias pode tornar a ADPF inócua e desnecessária, uma vez que existe o recurso extraordinário como meio de levar as discussões acerca da violação da Constituição até a instância máxima que é o STF. Aqui, a lição do direito alemão poderia - e ainda pode - ser aproveitada. mormente em face do que dispðe o $\$ 90$, alínea 2, frase 2, da Lei sobre o Bundesverfassungsgericht, onde se permite desconsiderar a exigência do esgotamento das vias judiciais. Ou seja, na Alemanha a exceção surge quando o recurso constitucional é de significado geral ou suceder ao impetrante um prejuízo grave e irreparável, caso seja remetido, inicialmente, à via judicial." (STRECK, op. cit., p. 642)

4 Art. $5^{\circ}$, inc. XXXV da Constituição: "a lei não excluirá da apreciação do Poder Judiciário lesão ou ameaça a direito;"

5 Traçando um paralelo entre a ADPF e o recurso constitucional alemão, CELSO BASTOS nos dá a 
mente aplicá-lo como deve ser. Para isso é preciso compreender a natureza da argüição de descumprimento de preceito fundamental.

A regulamentação da argüição de descumprimento de preceito fundamental na Lei $n^{\circ}$ 9.882/99 atribuiu à decisão nesta sede os mesmos efeitos daquela proferida nas ações direta de constitucionalidade e de inconstitucionalidade'. Vislumbra-se, portanto, uma eficácia geral, "pelo que a lei inconstitucional torna- se ineficaz para todos e para sempre, e não meramente não aplicada em um caso concreto." 2 Diante do formato estabelecido na Lei, editada com os vetos presidenciais, a argüição de descumprimento de preceito fundamental assume inegável caráter de ação constitucional de controle concentrado de constitucionalidade ${ }^{3}$. Nada anormal, portanto, é a produção de efeitos erga omnes ${ }^{4}$ e vinculante ${ }^{5}$ no plano normativo nacional ${ }^{6}$.

seguinte notícia: “... na Alemanha, a doutrina é assente no sentido de que quando a matéria versada no recurso constitucional for de interesse geral, não se exige o prévio esgotamento das instâncias ordinárias, o que representa uma exceção ao princípio da subsidiariedade do Verfassungbeschwerde. Conforme observou Klaus Schlaich, citando decisão da Corte Constitucional em matéria fiscal, nestas hipóteses a exaustão das vias judiciárias não é exigida. porque 'a decisão esperada (do recurso constitucional), além do caso concreto, irá esclarecer a situação jurídica de uma multiplicidade de casos que se apresentam de modo idêntico." (BASTOS, Celso Seixas Ribeiro. Argüição de descumprimento de preceito fundamental e legislação regulamentadora. In TAVARES, André Ramos: ROTHENBURG, Walter Claudius (org.). Argüição de descumprimento de preceito fundamental: análises à luz da Lei $n^{\circ}$ 9.882/99. São Paulo: Atlas, 2001.p. 105)

1 Art. $10, \S 3^{\circ}$ da Lei $n^{\circ} 9.882 / 99$. A argüição de descumprimento atende também às demais características do controle abstrato de constitucionalidade, dentre as quais podemos citar: a) é concentrado, na medida em que apenas o STF dispõe de competência quanto aos atos normativos federais e estaduais, e em face da Constituição Federal, para processar e julgar a ação direta de inconstitucionalidade; b) principal, na medida em que é suscitada por meio de uma ação autônoma que visa verificar, em tese, a validade do ato normativo; e c) objetivo porque, "à margem de tal ou qual interesse, tem em vista a preservação ou a reconstituição da constitucionalidade objetiva, quando o que avulta é a constante conformidade ou procura de conformidade dos comportamentos, dos actos e das normas com as regras constitucionais". (MIRANDA, Jorge. Manual de direito constitucional, 2. ed., Coimbra: Coimbra Ed., 1988, tomo 2, p. 313). Cf. CLĖVE, Clèmerson Merlin. Declaração de inconstitucionalidade de dispositivo normativo em sede de juízo abstrato e efeitos sobre os atos singulares praticados sob sua égide. Cadernos de Direito Constitucional e Ciência Política, n. 19, abr./jun. de 1997, p. 285.

2 CAPPELLETTI, Mauro. $O$ controle judicial de constitucionalidade das leis no direito comparado. Tradução por: Aroldo Plínio Gonçalves. 2ª ed. Porto Alegre: Sergio Antonio Fabris Editor, 1999, p. 119.

3 “A argüição de descumprimento de preceito fundamental decorrente da Constituição Federal é, então, uma forma de controle concentrado de constitucionalidade, sobre atos (normativos ou não) do Poder Público, aí compreendidas todas as esferas federativas." BASTOS e VARGAS, op. cit., p. 71.

4 "A eficácia erga omnes significa que declaração da constitucionalidade ou da inconstitucionalidade da lei se estende a todos os feitos em andamento, paralisando-os com o desfazimento dos efeitos das decisões neles proferidas no primeiro caso ou com a confirmação desses efeitos no segundo caso." (SILVA. op. cit., p. 60) "Caracterizando um verdadeiro exercício do direito de ação, o julgamento efetuado pelo Supremo Tribunal Federal refere-se à lei em tese, e os efeitos dessa decisão deverão atingir a todas as hipóteses em que possa haver sua incidência, vale dizer, a decisão que declara a inconstitucionalidade em tese é de alcance erga omnes, e reveste-se da autoridade da coisa julgada erga omnes, obrigando, portanto, não só o Poder judiciário, como todos os demais Poderes - Legislativo e Executivo". (FERRARI, Regina Maria Macedo Nery. Efeitos da declaração de inconstitucionalidade, $5^{2}$ ed., São Paulo: RT, 2004. p. 230-231)

5 "O efeito vinculante, que representa, em essência, a imposição obrigatória do cumprimento da decisão, constitui, no caso da ação direta de inconstitucionalidade, decorrência natural do sistema de 
"Apesar de o direito brasileiro adotar um complexo sistema misto de fiscalização de constitucionalidade, a argüição de descumprimento é um instrumento que complementa esse sistema, a fim de implementar a proteção da Constituição e dos direitos fundamentais. Portanto, a arguiição de descumprimento de preceito fundamental está inserida em um sistema de fiscalização de constitucionalidade e precisa ser entendida como parte desse sistema, devendo ser interpretada e aplicada em cotejo com outros instrumentos existentes no direito brasileiro que também proporcionam esse controle." I

Cumpre analisar em cada caso a existência de outro meio e sua eficácia. Não obstante, é possível delimitar a priori que o campo de investigação é o sistema de fiscalização concentrada de constitucionalidade. Aceitando-se um temperamento nos campos de incidência dos instrumentos aí inseridos, em que se verifica uma vedação estabelecida pelo Pretório Excelso de fiscalização de direito pré-constitucional nas ações diretas, leia-se ação direta de inconstitucionalidade e ação declaratória de constitucionalidade, a conclusão lógica sobre o meio eficaz de proteção dos preceitos fundamentais em jogo na aplicação dos dispositivos do Decreto-Lei $n^{\circ} 2.848$, de 07 de dezembro de 1940 , aos casos de intervenção médica na gestação de feto anencefálico é o cabimento de argüição de descumprimento de preceito fundamental ${ }^{2}$. Com isso, restaria preenchido o requisito da subsidiariedade.

Apenas para não deixar sem menção, cumpre, brevemente, lembrar que certamente não seria o caso de ação direta de inconstitucionalidade por omissão, tendo em vista prima facie a patente ineficácia do instituto para o presente caso que reclama uma declaração vinculante do órgão de cúpula do Poder Judiciário sobre a interpretação dos dispositivos do Código Penal e não a mora do legislativo para inserir qualquer nova regra. Sem contar que, para qualquer caso que reclame uma prestação positiva emergencial do Poder Público, ainda que seja a liberação de um procedimento médico para fins terapêuticos, a eficácia da ação direta de inconstitucionalidade por omissão fatalmente, na forma que foi revestida de normatividade pelo Supremo Tribunal Federal, configuraria um obstáculo para a tutela pretendida.

Nem se cogita a continuação de ações individuais como meio eficaz por razões óbvias. Ora, é justamente das decisões nestes casos que resulta a confusão de interpretações que se pretende findar por estarem, em tese, violando os preceitos fundamentais aduzidos. Não obstante, a duração dos processos, ainda quando se maneja o Habeas Corpus, traz o risco eminente de ineficácia do provimento.

controle de constitucionalidade." ZAVASCKI, Teori Albino. Eficácia das sentenças na jurisdição constitucional. São Paulo: RT, 2001, p. 53.. Sobre a diferença entre eficácia erga omnes e efeito vinculante, conferir: CLÈVE, A fiscalização abstrata ..., p. 240-259; FERRARI, op. cit., p. 237-245; CRUZ, op. cit., p. 174-176; MARTINS, Ives Gandra da silva e MENDES, Gilmar Ferreira. Controle concentrado de constitucionalidade: comentários à Lei n. 9.868 de 10/11/1999. São Paulo: Saraiva, 2001, p. 326-345. Sobre a coincidência dos fenômenos, conferir ANDRADE FILHO. Edmar Oliveira. Controle de constitucionalidade de leis e atos normativos. São Paulo: Dialética, 1997, p. 93-94.

7 "... os efeitos produzidos pela decisão no controle abstrato residem no plano normativo. Por isso, os atos singulares praticados com fundamento direto na lei reputada inconstitucional não são automaticamente desconstituídos pela decisão do STF. Os efeitos da decisão, reitere-se, repousam no plano da norma e não no plano normado (fato constituído pelo ato singular ou concreto praticado com fundamento na norma)." (CLÈVE, A fiscalizaçáo abstrata..., p. 253).

1 MANDELLI JR, op. cit., p. 132.

2 “... é o que ocorre, fundamentalmente, nas hipóteses relativas ao controle de legitimidade do direito pré-constitucional, do direito municipal em face da constituição Federal e nas controvérsias sobre direito pós-constitucional já revogado ou cujos efeitos já se exauriram. Nesses casos, em face do não-cabimento da ação direta de inconstitucionalidade, não há como deixar de reconhecer a admissibilidade da argüição de descumprimento." MEIRELLES, op. cit., p. 442. 
Prova cabal disso foi o desfecho do HC 84.025-6/RJ que teve em $1^{\circ}$ grau deferida liminar, na sequiência revogada pelo Presidente da Câmara e restabelecida pelo colegiado do respectivo órgão. Subiu ao Superior Tribunal de Justiça que suspendeu os efeitos da liminar e finalmente chegou ao Supremo Tribunal Federal quando, porém, já era impossível a tutela requerida, eis que o feto anencefálico havia sido parido, falecendo em menos de oito minutos após. A efícácia do meio nesse caso deve necessariamente ser cotejada com a celeridade do procedimento judicial. ${ }^{1}$

As únicas hipóteses que admitiriam um campo intercambiável de cabimento das ações diretas e da arguiição de descumprimento de preceito fundamental, e, portanto, afastariam a aplicação desta última, seriam (i) a mudança na orientação da Excelsa Corte sobre a fiscalização abstrata de constitucionalidade de dispositivos anteriores à promulgação da atual Constituição, ou (ii) a compreensão de que nas hipóteses em que a utilização da técnica da interpretação conforme à Constituição, com a conseqủente manutenção da regra no ordenamento jurídico, embora diminuida sua incidência em um ou mais casos específicos, não se enquadraria no objeto ressal vado do controle via ação direta de inconstitucionalidade.

Sobre a aplicabilidade da técnica de controle de constitucionalidade nominada de interpretação conforme à Constituição ${ }^{2}$, não há resistência doutrinária ou jurisprudencial digna de conhecimento. Ela está consagrada, como bem leciona BONAVIDES:

"A interpretação das leis 'conforme a constituição', se já não tomou foros de método autônomo na hermenêutica contemporânea, constitui fora de toda a dúvida um princípio largamente consagrado em vários sistemas constitucionais. Decorre em primeiro lugar da natureza rígida das Constituições, da hierarquia das normas constitucionais - de onde promana o reconhecimento da superioridade da norma constitucional - e enfím do caráter

1 "O problema que se apresenta é quanto à celeridade dos meios existentes. Afinal, a todo direito corresponde uma ação judicial tendente a preservá-lo ou assegurá-lo quando violado." (BASTOS, op. cit., p.80) A proteção a ser oferecida pelo ordenamento jurídico para este especial viés do direito fundamental (violação ou ofensa causada por ato do Poder Público) deve ser suficiente. Tendo em vista a aplicação imediata dos direitos fundamentais, infere-se um verdadeiro dever de atuação do Judiciário para garantir a proteção razoável aos preceitos fundamentais em jogo. Não se olvida que o desejo e necessidade de agilidade no andamento dos processos judiciais elevou à condição de direito fundamental sua razoável duraçāo (Constituição Federal, art. $5^{\circ}$, inc. LXXVIII - a todos, no âmbito judicial $e$ administrativo, são assegurados a razoável duração do processo e os meios que garantam a celeridade de sua tramitação ). Jamais poderá ser considerada razoável duração do processo aquela que impossibilite a tutela. No caso de gestante de feto anencefálico, o prazo máximo do processo terá necessariamente que ser inferior ao restante de meses de gestação normal, porém aí só se estará dentro do prazo máximo. A duração razoável deve ser ainda menor para que haja efetividade. Desta forma, pode-se concluir, sem dúvidas, que inexiste outro meio mais eficaz que a argüição de descumprimento de preceito fundamental para o caso.

2 Conferir, entre outros, (i) no direito alemão: FRIESENHAHN, Ernst. La giurisdizione costituzionale nella Repubblica Federale Tedesca, Milano, Giuffrè, 1973, p. 92; BÉGUIN, Jean-Claude. Le controle de la constitutionalité dês lois em Republique Fédérale d'Allemagne. Paris: Econômica, 1982, p. 185; HESSE, Konrad. Escritos de derecho constitucional, Madrid, Centro de Estudios Constitucionales, 1992. p. 50 e Elementos de direito constitucional..., p. 70; (ii) no direito espanhol: ENTERRÍA, Eduardo Garcia de. La Constiutción como norma y el tribunal constitucional. Madrid: Civitas, 1991, p. 95; (iii) no direito italiano: JAEGGER, Nicola. Sui limiti di efficacia delle decisioni della corte costituzionale, Rivista di Diritto Processuale, Padova, 1958, p. 364-383; MONTESANO, Luigi. Norma e formula legislativa nel giudizio costituzionale, Rivista di Diritto Processuale, Padova, 1958, p. 524-534; ZAGREBELSKY, Gustavo. La giustizia costituzionale, Bologna, Il Mulino, 1982, p. 292; MANNO, Thierry di. Le juge constitutiçnnel et la techique dês décisions "interprétatives" en France et en ltalie. Paris: Econômica, 1997; (iv) no direito português: MIRANDA, Jorge. Manual de direito constitucional, 2. ed., Coimbra: Coimbra Ed., 1988, p. 232; CANOTILHO, Jose Joaquim Gomes, op. cit., p. 1225. 
de unidade que a ordem jurídica necessariamente ostenta.

Em rigor não se trata de um princípio de interpretação da Constituição, mas de um princípio de interpretação da lei ordinária de acordo com a Constituição." I

Os efeitos da aplicação da técnica em comento no caso sob análise não geram qualquer atrito com o que até então tem sido praticado ${ }^{2}$, eis que "por meio da interpretação conforme [...] a Corte reduz/limita o campo de incidência dos elementos tipológicos da norma, por meio de interpretação restritiva" ${ }^{3}$, tal qual se pleiteia para a alegada incidência questionável dos dispositivos penais relativos ao abortamento que tem sido operada em casos dispersos na jurisdição pátria. Ora, se "oportunidade para a interpretação conforme a Constituição existe sempre que determinada disposição legal ofereça diferentes possibilidades de interpretação, sendo algumas delas incom- patíveis com a Constituição" 4 e se na argüição proposta perante o Supremo Tribunal Federal argumenta-se com a ofensa a preceitos fundamentais decorrentes de uma particular leitura dos dispositivos penais que regem o aborto, a conclusão lógica é a possível aplicação da referida técnica.

\subsection{RELEVÂNCIA DO FUNDAMENTO DA CONTROVÉRSIA CONSTITUCIONAL SOBRE LEI OU ATO NORMATIVO FEDERAL, INCLUSIVE ANTERIORES À CONSTITUIÇÃO}

Esse dispositivo da Lei $n^{\circ} 9.882 / 99$ tem gerado uma grande celeuma doutrinária por conta do difundido entendimento de que ele encerra uma modalidade adjacente de argüição de descumprimento de preceito fundamental, chamada de incidental ${ }^{5}$. Para os fins

1 BONAVIDES, Paulo. Curso de direito Constitucional, 14² ed., São Paulo: Malheiros, 2004, p. 517-518. Não se pretende aqui discutir se a interpretação conforme é um princípio constitucional, um princípio da interpretação constitucional ou uma técnica de controle de constitucionalidade. Sobre o tema. conferir APPIO, op. cit., p. 27-37.

2 "A 'interpretação conforme' é técnica conhecida do Supremo desde antes da Constituição de 1988." (CLÈVE, A fiscalização ..., p. 263)

3 CRUZ, op. cit., p. 182. No mesmo sentido, VELOSO, Zeno. Controle de constitucionalidade. Belo Horizonte: Del Rey, 2000, p. 128.

4 CASTILHO NETO. Arthur de. Reflexōes críticas sobre a ação direta de constitucionalidade no Supremo Tribunal Federal. RPGR. n. 2, Brasília. 1993, p. 14.

5 Não há um consenso doutrinário sobre a existência de uma modalidade de ADPF autônoma e outra incidental. MENEZES DIREITO assim entende: "Embora prestigiada por autores de peso, não creio que a Lei, com o veto ao inciso II do art. $2^{\circ}$, autorize interpretação que admita a possibilidade de propositura da argülição incidenter tantum. A argúição incidental não está cogitada no texto em vigor. Se não tivesse havido o veto, seria possível admiti-la. Mas, a interpretação construtiva, no caso, não me parece, com respeitosa vênia aos mestres que entendem em sentido contrário, adequada. A tanto não chego com a leitura do parágrafo único do art. $1^{\circ}$. Os expressamente legitimados podem, sim. propor a argüição naquela hipótese, com a prova de que existe a controvérsia judicial relevante sobre a aplicação do preceito constitucional, mas já considerando as decisões judiciais existentes, assim, por exemplo, aquelas decorrentes de numerosas medidas liminares enfrentando a aplicação de preceito fundamental. A admissão da argúição incidental, no rigor da doutrina, por outro lado, levaria, necessariamente, a ampliar o rol dos legitimados para propô-la, o que, também, não me parece possível. A hipótese de os legitimados apresentarem a argüição estando em curso a ação judicial é, ainda, argüição na modalidade direta, não incidental, que seria aquela, e somente aquela, que qualquer das partes ou o próprio órgão judicial poderia suscitar, como no caso do incidente de inconstitucionalidade nos Tribunais. Na minha compreensão, não há argúição incidental, mas, sim, a possibilidade do deferimento da medida liminar que atinja processos em andamento, efeito possível, mas não necessário, porque o comando legal apenas determina que ela poderá consistir. $O$ fato de atingir processos em andamento, a meu juízo, não configura a modalidade 
incidental, nos termos do texto em vigor." (Op. cit, p. 169) Em sentido contrário, entende ANDRÉ RAMOS TAVARES: "Há uma argüição incidental, ao lado daquela exercida por ação, porque a controvérsia com 'relevante fundamento' à qual faz menção o parágrafo único do art. $1^{\circ}$ só pode ser aquela que se apresenta em juízo, e não qualquer controvérsia que se instale entre particulares. A 'controvérsia', no sentido técnico, é aquela instaurada perante o judiciário, ou levada ao conhecimento deste. Auxilia o reconhecimento dessa modalidade a apreciação do disposto no inciso $V$ do art. $3^{\circ}$ da Lei de Argüição, que exige que se apresente, conjuntamente com a petição inicial, se 'for o caso, a comprovação de existência de controvérsia judicial relevante sobre a aplicação do preceito fundamental que se considera violado.' O cumprimento do artigo impõe-se apenas para a argüição incidental. Daí a eventualidade ('se for o caso') da aplicação do mesmo." (Op. cit., p. 64) É preciso, no entanto, deixar claro que, seja qual for o entendimento, não há fundamento para uma separação de hipóteses de cabimento. Neste sentido, afirma MANDELLI JR que mesmo entendendo existir uma modalidade de arguição de descumprimento de preceito fundamental autônoma e outra incidental, não há restrição do cabimento de uma e outra no art. $1^{\circ}$ da Lei $n^{\circ} 9.882 / 99$, como se o caput identificasse uma e o parágrafo único outra. "Essa correspondência não se justifica, pois limitaria os objetos sindicáveis de cada argüição. Adotada essa posição, não seria possível, por exemplo, a argüição autônoma que tivesse como objeto lei anterior à Constituição; nem mesmo a argüição incidental de ato concreto (não normativo) do Poder Público. A restrição do objeto não se harmoniza com a finalidade da argùição que pretendeu superar a jurisprudência restritiva do STF que se formou em torno do objeto da ação direta de inconstitucionalidade, não admitindo o controle concentrado de constitucionalidade do direito municipal e do direito pré-constitucional." (MANDELLI JR, op. cit.. p. 106-107. Conferir ainda SOUZA, op. cit., p. 436) ROTHENBURG concilia os entendimentos aduzindo que "os textos devem ser compreendidos como informadores de uma mesma norma, que traça o perfil completo da arguição de descumprimento de preceito fundamental, em ambas as modalidades (direta ou incidental), estabelecendo que o objeto poderá ser, em qualquer caso, ato do Poder Público, compreendidos "lei ou ato normativo federal, estadual ou municipal, incluídos os anteriores a Constituiçăo', desde que seja 'relevante o fundamento da controvérsia constitucional'." (ROTHENBURG. op. cit., 206-207). E arremata: "a condição de admissibilidade da relevância da questão constitucional aplica-se a ambas as modalidades. $\mathrm{Ccm}$ isso, cresce a margem de apreciação do Supremo Tribunal Federal". (Ibid., p. 210). Apenas para contribuição no debate entre aqueles que aceitam a existência de duas modalidades distintas de arguiição de descumprimento de preceito fundamental, faz-se necessária a seguinte colocação. Se a arguiição de descumprimento de preceito fundamental veio justamente a propiciar o controle de constitucionalidade nos casos em que as outras açōes do controle abstrato nāo alcançavam. não haveria razão de ser para uma pretensa auto-constrição de seu cabimento, pois, como disposto na Lei $n^{\circ} 9.882 / 99$, ela já é instrumento subsidiário. Esta subsidiariedade, no entanto, não pode ser usada contra ela mesma. Não é plausível deixar de admitir a arguição de descumprimento de preceito fundamental autônoma por que cabível arguiição de descumprimento de preceito fundamental incidental. "Imaginemos que o requisito da relevância do fundamento da controvérsia constitucional se aplicasse apenas a arguiç̧ão incidental. O Supremo Tribunal Federal perderia a oportunidade de poder recusar arguliçőes diretas de diminuta relevância. Para ambas as modalidades de arguiç̧ão (tanto a direta quanto a incidental), e certo que se exige o descumprimento de preceito fundamental, ou s.ja, o Supremo Tribunal Federal avaliara a fundamentalidade do preceito constitucional descumprido. A avaliação da relevância da controvérsia constitucional completa esse quadro de apreciação discricionária - verdadeira filtragem realizada pelo Supremo Tribunal Federal. Logo, não tem sentido o Supremo Tribunal apenas poder avaliar essa relevância em relação à arguição incidental e não também em relação à arguição direta. Se 'lei ou ato normativo federal, estadual ou municipal, inclú́dos os anteriores a Constituição' fossem objetos exclusivos da arguiç̧ão incidental, estaríamos esvaziando desmesuradamente à arguição direta, excluindo indevidamente tais atos normativos da compreensiva expressão ato do Poder Público (constante do caput do art. I). Também não teria sentido retirar da argüição direta a possibilidade de discutir o descumprimento de preceito fundamental por atos normativos de quaisquer esferas da federação, incluídos os pre-constitucionais. Esses atos já podem ser objeto do controle concreto e difuso de constitucionalidade: veja-se que o art. 102, inciso III, da Constituição, não restringe o cabimento de recurso extraordinário." (ROTHENBURG, op. cit, p. 204-205) 
deste estudo, não é necessário adentrar a questão.

Já foi aludido no item II que os atos jurisdicionais enquadram-se no conceito de atos do Poder Público e que a interpretação de atos legislativos na construção de normas de decisão pode gerar lesão a preceitos fundamentais ${ }^{1}$. Assim, mais do que explicitar tal circunstância, o inciso I do parágrafo único do art. $1^{\circ}$ da Lei $n^{\circ} 9.882 / 99$ serve para a emergência do controle de constitucionalidade dos atos normativos municipais e outros, em qualquer esfera, anteriores à Constituição. $O$ dispositivo em comento pode ser compreendido, então, como uma tentativa de exemplificar os casos de cabimento de argüição de descumprimento de preceito fundamental mais sujeitos a resistência doutrinária e jurisprudencial.

O que importa nesta previsão legal é a explicitação de que as controvérsias envolvendo preceitos fundamentais com certa proeminência axiológica simplesmente não devem dei- xar de ser analisadas pelo órgão de cúpula do judiciário pátrio, em virtude da grande comoção social que geram ${ }^{2}$. É o caso da antecipação do parto de fetos anencefálicos. ${ }^{3}$

"Cumpre, no particular, não olvidar que um dos objetivos que inspirou a criação da ADPF foi o de possibilitar a antecipação de decisões do Supremo Tribunal Federal sobre temas constitucionais relevantes, que, antes desta ação, só poderiam ser examinadas pelo Supremo depois de muito tempo, após longas batalhas judiciais, quando já instalado um deletério clima de insegurança jurídica." 4

Mesmo para aqueles que vejam aí um quarto requisito para o cabimento da ação constitucional, não haveria óbice na admissibilidade do pleito relativo à antecipação terapêutica de parto de feto anencefálico. Para tanto, sequer seria preciso dispender muitas palavras para indicar a relevância da controvérsia. $O$ interesse público na solução da sensível questão já torna imprescindível o pronunciamento da Corte Suprema ${ }^{5}$. Não obstante, reitera-se que

1 "A possibilidade de incongruências hermenêuticas e confusōes jurisprudenciais decorrentes dos pronunciamentos de múltiplos órgãos pode configurar uma ameaça a preceito fundamental (pelo menos, ao da segurança jurídica), o que também está a recomendar uma leitura compreensiva da exigência aposta à lei da argüição, de modo a admitir a propositura da ação especial toda vez que uma definição imediata da controvérsia mostrar-se necessária para afastar aplicações erráticas, tumultuárias ou incongruentes, que comprometam gravemente o princípio da segurança jurídica e a própria idéia de prestação judicial efetiva. Ademais, a ausência de definição da controvérsia - ou a própria decisão prolatada pelas instâncias judiciais - poderá ser a concretização da lesão a preceito fundamental." (MEIRELLES, op. cit., p. 444)

2 O Supremo Tribunal Federal tem certa discricionariedade para conhecer das argüições de descumprimento de preceito fundamental, a qual decorre "do fato de que toda Corte que exerce a jurisdição jurisdicional [sic] não é somente um órgão judiciário comum, mas órgão político diretivo das condutas estatais, uma vez que interpreta o significado dos preceitos constitucionais, vinculando todas as condutas dos demais órgãos estatais e como tal deve priorizar os casos de relevante interesse público." MORAES, Alexandre de. Comentários à Lei $n^{\circ} 9.882 / 99$ - Argüição de descumprimento de preceito fundamental. In TAVARES, André Ramos; ROTHENBURG, Walter Claudius (org.). Argüição de descumprimento de preceito fundamental: análises à luz da Lei n 9.882/99. São Paulo: Atlas, 2001, p. 29.

3 “... o Tribunal poderá conhecer da argüiçāo de descumprimento toda vez que o princípio da segurança jurídica restar seriamente ameaçado, especialmente em razäo de conflitos de inteıpretação ou de incongruências hermenêuticas causadas pelo modelo pluralista de jurisdição constitucional." MEIRELLES, op. cit., p. 446.

4 BASTOS, Argüição de descumprimento ..., p. 104.

5 "É fácil de ver também que a fórmula da relevância do interesse público para justificar a admissão da argüição de descumprimento (explícita no modelo alemão) está implícita no sistema criado pelo legislador brasileiro, tendo em vista especialmente o caráter marcadamente objetivo que se conferiu ao instituto." (MEIRELLES, op. cit., p. 446) 
ainda assim os demais pressupostos restam configurados.

"Não basta, pois, que haja relevante controvérsia; o que é necessário demonstrar, como ponto principal, é que a controvérsia tenha por base a discussão acerca da violação de preceito fundamental." 1

Não se perca de vista que a configuração de um quarto requisito para o cabimento da arguiição de descumprimento de preceito fundamental deve ser compreendido em cotejo com todos os dispositivos da Lei $n^{\circ} 9.882 / 99$. os quais não contemplam de modo expresso sequer sua indispensabilidade (mas sim um "também"), quanto mais sua exclusividade para qualquer espécie de ação que se venha a admitir na doutrina e jurisprudência. Desta forma, parece que o mais acertado é compreender que a relevância da controvérsia constitucional configura-se como um requisito complementar a corroborar a autoridade do Supremo Tribunal Federal para conferir uniformidade de tratamento jurídico às questões constitucionais mais sensíveis.

\section{CONCLUSÃO E RESPOSTA AO QUESITO ÚNICO}

Isto posto, responde-se ao quesito proposto afirmativamente, ou seja, apresenta-se a ar- güição de descumprimento de preceito fundamental como meio processual hábil para tratamento do caso da antecipação de parto de feto anencefálico, inclusive para que o Supremo Tribunal Federal possa decidir com caráter vinculante e efeito contra todos.

É o que nos parece.

Curitiba, 19 de abril de 2005.

JOSÉ AFONSO DA SILVA

Professor Titular aposentado da USP. Professor no Curso de Direito Urbanístico na Pós-Graduação da USP. Professor Livre-Docente de Direito Financeiro, de Processo Civil e de Direito Constitucional da Faculdade de Direito da UFMG. Fundador e Presidente da Associação Brasileira de Constitucionalistas Democráticos. Presidente da Seção Brasileira do Instituto Iberoamericano de Derecho Constitucional.

\section{CLÈMERSON MERLIN CLÈVE}

Professor Titular de Direito Constitucional da UniBrasil e da UFPr. Professor nos Cursos de Mestrado e Doutorado. Mestre e Doutor em Direito. Pós-graduado pela Université Catholique de Louvain (Bélgica). Professor convidado do Programa de Doutorado da Universidad Pablo de Olavide (Sevilha/Espanha). Vice-Presidente da Seção Brasileira do Instituto Iberoamericano de Derecho Constitucional. 